Review

\title{
Carbon Fluxes in Sustainable Tree Crops: Field, Ecosystem and Global Dimension
}

\author{
Giuseppe Montanaro $^{1, * \mathbb{D}}$, Davide Amato ${ }^{1} \mathbb{D}$, Nunzio Briglia $^{1}$, Carlo Russo ${ }^{2} \mathbb{D}$ and Vitale Nuzzo $^{1}(\mathbb{D}$ \\ 1 Department of European and Mediterranean Cultures: Architecture, Environment, and Cultural \\ Heritage (DICEM), Università degli Studi della Basilicata, 85100 Poteza, Italy; davide.amato@unibas.it (D.A.); \\ nunzio.briglia@unibas.it (N.B.); vitale.nuzzo@unibas.it (V.N.) \\ 2 Department of Economy Management and Territory, University of Foggia, Via Da Zara 11, 71121 Foggia, Italy; \\ carlo.russo@unifg.it \\ * Correspondence: giuseppe.montanaro@unibas.it; Tel.: +39-3913-808337
}

Citation: Montanaro, G.; Amato, D.; Briglia, N.; Russo, C.; Nuzzo, V. Carbon Fluxes in Sustainable Tree Crops: Field, Ecosystem and Global Dimension. Sustainability 2021, 13, 8750. https://doi.org/10.3390/ su13168750

Academic Editor: José Manuel Mirás-Avalos

Received: 16 July 2021

Accepted: 3 August 2021

Published: 6 August 2021

Publisher's Note: MDPI stays neutral with regard to jurisdictional claims in published maps and institutional affiliations.

Copyright: (c) 2021 by the authors. Licensee MDPI, Basel, Switzerland. This article is an open access article distributed under the terms and conditions of the Creative Commons Attribution (CC BY) license (https:// creativecommons.org/licenses/by/ $4.0 /)$.

\begin{abstract}
Carbon (C) budget at cropping systems has not only agronomic but also environmental relevance because of their contribution to both emissions and removals of greenhouse gases (GHGs). Ideally, sustainable orchards are expected to remove atmospheric $\mathrm{CO}_{2}$ at a rate greater than that of the emissions because of (i) optimized biology of the system and (ii) reduced on-site/offsite inputs sourced by the technosphere. However, such a computation might produce inconsistent results and in turn biased communication on sustainability of the cropping systems because $\mathrm{C}$ accounting framework(s) are used under unclear context. This study examined the sustainability of orchards in terms of impact on GHGs focusing its significance at the field, ecosystem and global dimension analyzing some operational aspects and limitations of existing frameworks (e.g., net ecosystem carbon balance (NECB), life cycle assessment (LCA)). Global relevance of sustainable orchard was also discussed considering the $\mathrm{C}$ sequestration at cropland as instructed by Intergovernmental Panel on Climate Change (IPCC). The uniqueness of olive tree lifespan duration and C sequestration is discussed within the Product Environmental Footprint of agrifood product. The paper also highlighted overlapping components among the NECB, LCA and IPCC frameworks and the need for an integrated $\mathrm{C}$ accounting scheme for a more comprehensive and detailed mapping of sustainability in agriculture.
\end{abstract}

Keywords: carbon sequestration; GHG; NECB; LCA; olive; PEF; soil organic carbon; tree biomass

\section{Introduction}

Sustainability in agriculture has recently gained renewed interest as a result of the definition of Sustainable Development Goals by United Nations [1]. A comprehensive assessment of sustainability of agricultural cropping systems should simultaneously refer to its economic, environmental and social performance, making it a complex challenge [2] Hence, any sustainable strategy should focus the preservation of agricultural productivity and food security reducing greenhouse gases (GHGs) emissions and increasing atmospheric $\mathrm{CO}_{2}$ removals.

Agricultural lands are natural ecosystems managed by farmers that play a relevant role in emissions of the major GHGs $\left(\mathrm{CO}_{2}, \mathrm{CH}_{4}\right.$ and $\left.\mathrm{N}_{2} \mathrm{O}\right)$ involved in increasing radiative forcing of Earth's atmosphere [3,4]. The impact of agriculture on atmospheric GHGs balance is intimately linked to farmers' behavior in terms of management practices they adopt. For example, mechanized and chemically fertilized crops significantly contribute to GHGs emissions mainly due to fossil fuel consumption for increased use of some external inputs (e.g., pesticides, irrigation water, mineral nutrients), machinery production and maintenance, and field oxidation of minerals supplied $[5,6]$.

In addition, cropland intensification leads to an overexploitation of natural capital (e.g., soil, water). For example, the use of mineral fertilizers in place of organic ones 
and soil tillage contribute to soil organic carbon (SOC) depletion (and in turn that of the SOC-mediated ecosystem services) [7,8]. Crop management also influences $\mathrm{CH}_{4}$ and $\mathrm{N}_{2} \mathrm{O}$ fluxes mainly through soil tillage and mineral nutrition $[9,10]$.

Within the agricultural sector there are several sustainable technologies and practices able to support climate change mitigation which encompass the reduction (or avoidance) of GHGs emissions and enhancement of atmospheric $\mathrm{CO}_{2}$ removals. For example, use of organic fertilization, crop residues management (mulching them in loco rather than burn), soil management (no tillage, use of cover crops), irrigation (use of localized irrigation and renewable energy for pumping) and land use change (e.g., increase perennials) [10-12].

At the 2015 Paris UNFCCC-COP21 climate conference, the " $4 \%$ " initiative was launched as tool for partial offset of global anthropogenic emissions boosting the sequestration of atmospheric $\mathrm{CO}_{2}$ into cultivated soil and soliciting further discussion on sustainable management practices (e.g., agroforestry, biochar, improved grazing and restoration of degraded soils) [13]. These practices collectively promote soil recarbonization at a variable SOC rate ranging from approx. 0.2 to $5 \mathrm{Mg} \mathrm{C} \mathrm{ha}^{-1} \mathrm{yr}^{-1}$ [14] and contribute to restore soil structure and function, and in turn the flow of related ecosystems services [8]. Hence, while currently crop activities (on farm crop production and land use change category) are indicted to be responsible for $8-20 \%$ of global anthropogenic GHGs emissions [15], after the switch to a sustainable format they can be an ally in climate change mitigation mainly because of the ability of plants to capture atmospheric $\mathrm{CO}_{2}$ and because of reduction of practice-induced GHGs emissions.

As orchards are part of wide natural ecosystems, anthropogenic interferences on field carbon fluxes are influential on the overall ecosystems carbon budget. For example, to accomplish the target of any cropping process $\mathrm{C}$ is exported from the orchard (and in turn from ecosystems) as fruit or biomass. Similarly huge amounts of $C$ are often exported because crop (e.g., pruning) residues are burning outside the field [16]. By contrast, ecosystems might store $C$ when it is imported as organic fertilizers (e.g., manure, compost), adopting cover crops, and mulch in loco of pruning residues [17]. In addition, adoption of no-tillage strategy reduced soil $\mathrm{CO}_{2}$ respiration promoting SOC conservation [18]. Hence, all these import-export $\mathrm{C}$ fluxes should be quantified if a more accurate sustainability have to be determined at an ecosystem scale.

Agricultural production processes require external on-site inputs (e.g., machinery, pesticides, fertilizers, plastic trays) supplied by the technosphere. In addition, there are often others off-site inputs (e.g., transportation, packhouse processing) essential for the whole agrifood production chain. The use of external inputs supplied by the technosphere implies direct or indirect GHGs emissions [12] imputable to agriculture. Accounting for these GHGs emissions would help to identify related sources and possible reduction strategies contributing to reinforce sustainability of agriculture at "global" scale.

Figure 1 illustrates the agricultural production as part of a natural ecosystem and interactions with various spheres identifying field, ecosystem and global dimensions. The flow of ecosystem services (e.g., fruit/vegetable, soil erosion control, regulating atmospheric $\mathrm{CO}_{2}$ ) from ecosystems to the society (anthroposphere) and the potential flow of environmental protecting actions from society to ecosystems are also highlighted (Figure 1).

Climate change together with increasing food demand due to growing global population and with changing of human diet towards plant-based food which are perceived environmentally friendly [19] are collectively challenging agriculture, making the wide adoption of sustainable practices urgent. However, sustainability assessments of an agricultural product involving GHGs flux estimates might have different structures depending on the target to be pursued (e.g., agronomical, ecological, societal) and on the boundaries considered (i.e., field, ecosystem and global).

Despite growers being the key-factor for wide scale application of sustainable practices, some growers' perspective links the benefits of field sustainable practices to the expected increased yield and to enhanced agronomic traits (e.g., soil water holding capacity, nutrient release, $\mathrm{pH}$ buffer capacity) induced by increased soil C [20]. In view of the potential 
role of agriculture to support climate change mitigation, this view needs to be expanded, embracing different levels of $C$ benefits achievable at ecosystem and global dimensions. However, the carbon balance of agrifood produce carried out in a life cycle perspective could became a way to differentiate own production with respect to competitors. In this context, the Carbon Footprint certification according to UNI EN ISO 14067:2018 could play a very important role in increasing farm competitiveness and promote good sustainable agricultural practices [21-23].

With this background, this study examines the carbon fluxes related to orchard production systems at farm, ecosystem and global dimensions, and discusses possibilities of integration of various accounting GHGs frameworks to improve the assessment of certain aspects of environmental performance of sustainable agriculture.

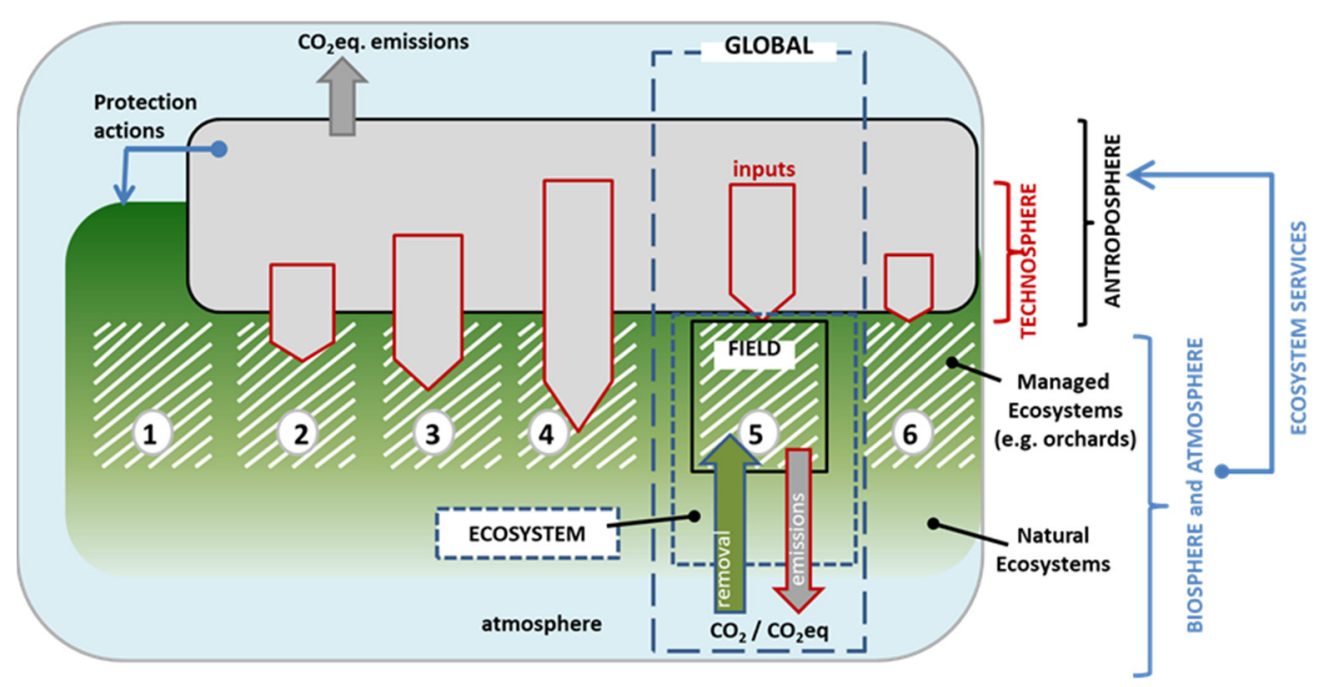

Figure 1. Schematic representation of the various interactions between managed (field) and natural ecosystems and the anthroposphere within an agricultural production context. Different fields (from 1 to 6) (white dashed areas) receive different amounts of inputs from the technosphere: field \#1, do not receive any input; field \#2-4 receive increasing inputs which are used both on-site and at field scale (e.g., pesticides, chemical fertilizers, machinery, transportation); field \#5,6, receive off-site technological inputs related to production steps occurring solely outside the field (e.g., transportation of olive to the mill, crushing, extraction and bottling of the olive oil). Note that the field, ecosystem and global frameworks (dashed box) have been drawn for orchard \#5 for example purpose but they apply to all orchards. The flow of the ecosystems services (e.g., fruit/vegetable, soil erosion control, regulating atmospheric $\mathrm{CO}_{2}$ ) from ecosystems to the society (anthroposphere) and the potential flow of actions from society to ecosystems are reported as well. The broad arrows represent the emissions (from orchard to atmosphere) or removals (from atmosphere to orchard) of $\mathrm{CO}_{2}$ or $\mathrm{CO}_{2}$ equivalent $\left(\mathrm{CO}_{2} \mathrm{eq}\right.$ ).

\section{Farm Dimension}

Most of the 20th century has been dominated by the dependence of agriculture on mineral fertilization as legacy of Liebig's discovery of the role of mineral elements and thanks to the growing chemical fertilizers industry [24]. Since the 1940s, soil organic matter has been progressively associated to various agronomic benefits leading to improved productivity and soil resilience [25]. Nowadays, there are evidences on the limited perception by group of farmers concerning the benefits linked to increased soil organic matter (e.g., climate change effects) apart from its capacity of increasing productivity [20].

Soil fertility is associated to productivity often because it is tailored to the capability of soil to supply nutrients to meet plant demand, however other factors (e.g., soil moisture, soil temperature, $\mathrm{pH}$, toxic elements, salts) might limit productivity [26]. Hence, soil fertility should not be limited to productivity but embrace a large bundle of soil functions including physical and biological fertility and buffering capacity. Soil carbon is behind these fertility types and related services $[8,17]$ to the extent that they have been proposed as key factor for the assessment of economic value of SOC [27]. 
The increase of soil organic matter (and in turn SOC) is affected by several factors, including quality/quantity of organic input, environmental conditions (e.g., soil moisture, texture, temperature), and the initial content of SOC to the extent that these factors are the core of most SOC models [28]. In addition, how the soil microbial community processes $C$ influences its sequestration. Microbial carbon use efficiency (CUE) (microbial biomass $C$ increment during growth per amount of organic $C$ used) impacts $C$ accumulation to the extent that integrating multi-enzyme stoichiometry and $C$ balance approaches are emerging [29]. A recent perspective study [30] highlights the various ecological unknowns influencing CUE and in turn CUE management limitations in agricultural soils for greater soil C storage.

Carbon inputs are the main driver for increasing $C$ stocks, although at a variable rate depending also on eventual combination with other sustainable practices adopted (e.g., cover crops, no-tillage). The meta-analysis proposed by Aguilera et al. [14] showed that approx. $50 \%$ of the $\mathrm{C}$ input is sequestered as SOC and that the highest sequestration rate $\left(\sim 5.1 \mathrm{Mg} \mathrm{C} \mathrm{ha}^{-1} \mathrm{yr}^{-1}\right)$ was generated by C inputs exceeding $10 \mathrm{Mg} \mathrm{C} \mathrm{ha}^{-1} \mathrm{yr}^{-1} . \mathrm{A}$ significant correlation between SOC storage and yield increment was reported for winter wheat and summer maize [31], however, increasing soil organic matter per se does not necessarily increase the yield especially when nutrients are supplied through mineral fertilizers [32].

At perennial crops carbon might be sequestered also in others compartments of the orchard ecosystems such as above-belowground biomass and litter [33]. Hence, orchards might act as carbon sink contributing to climate change mitigation and to the achievement of a low carbon society. Awareness of such "societal" sustainability have been recently embedded in a European legislation package to the extent that estimates of the C pools variation at perennial crops have been included in the Cropland category of the LULUCF domain within the annual GHGs monitoring and reporting national procedures compiled to fulfil the Kyoto Protocol commitments [34]. The biogeochemical cycle of SOC is pivotal for plant production also because native soil nitrogen (the most important nutrient for yield) is available through soil organic matter mineralization. Therefore, the mineralization rate along with the season should be characterized to check for adequate $\mathrm{NO}_{3}^{-}$availability for the crop, keeping in mind that $\mathrm{NO}_{3}^{-}$is leached or emitted in atmosphere as $\mathrm{N}_{2} \mathrm{O}$ when exceeding plant uptake. Within a GHG balance, soil $\mathrm{N}_{2} \mathrm{O}$ emissions partly offset the benefits from soil organic carbon storage [35].

\section{Ecosystem Dimension}

The lack of a clear cause $\rightarrow$ effect of increasing SOC on yield discussed above emphasizes that to gain more relevance carbon management should be re-examined within the whole $C$ fluxes at orchard systems within an agroecology context. For this purpose it is mandatory to disentangle field $C$ fluxes at ecosystem scale and the potential impact of some manageable options on that fluxes. The main focus at ecosystem dimension towards the definition of orchard sustainability would be the net ecosystem productivity (NEP) which might be positive (sink) or negative (source) assuming the ecosystem as the reference system. From basic ecology it results that:

$$
\mathrm{NEP}=\mathrm{NPP}-R_{\mathrm{h}}
$$

where NPP (net primary productivity) is the total carbon removed (and partly sequestered) by the plants through photosynthesis, and $R_{\mathrm{h}}$ is the heterotrophic component of the soil respiration. It follows that maximize sustainability crop management should maximize NPP and minimize $R_{\mathrm{h}}$ in order to achieve a NEP value as high as possible. For this purpose, the adoption of cover crops is a relevant strategy to significantly increase the amount of atmospheric C captured as NPP by the ecosystem. For example, in a peach orchard cover crop biomass might help to remove from the atmosphere approx. $155 \mathrm{~g} \mathrm{C} \mathrm{m}^{-2} \mathrm{yr}^{-1}$ (approx. 25\% of the total NPP) (Figure 2). The amount of C derived from cover crops 
might vary from approx. $80 \mathrm{~g} \mathrm{C} \mathrm{m}^{-2} \mathrm{yr}^{-1}$ in traditional olive plantation [36] up to $200-500 \mathrm{~g} \mathrm{C} \mathrm{m}^{-2} \mathrm{yr}^{-1}$ in vineyard [37,38].

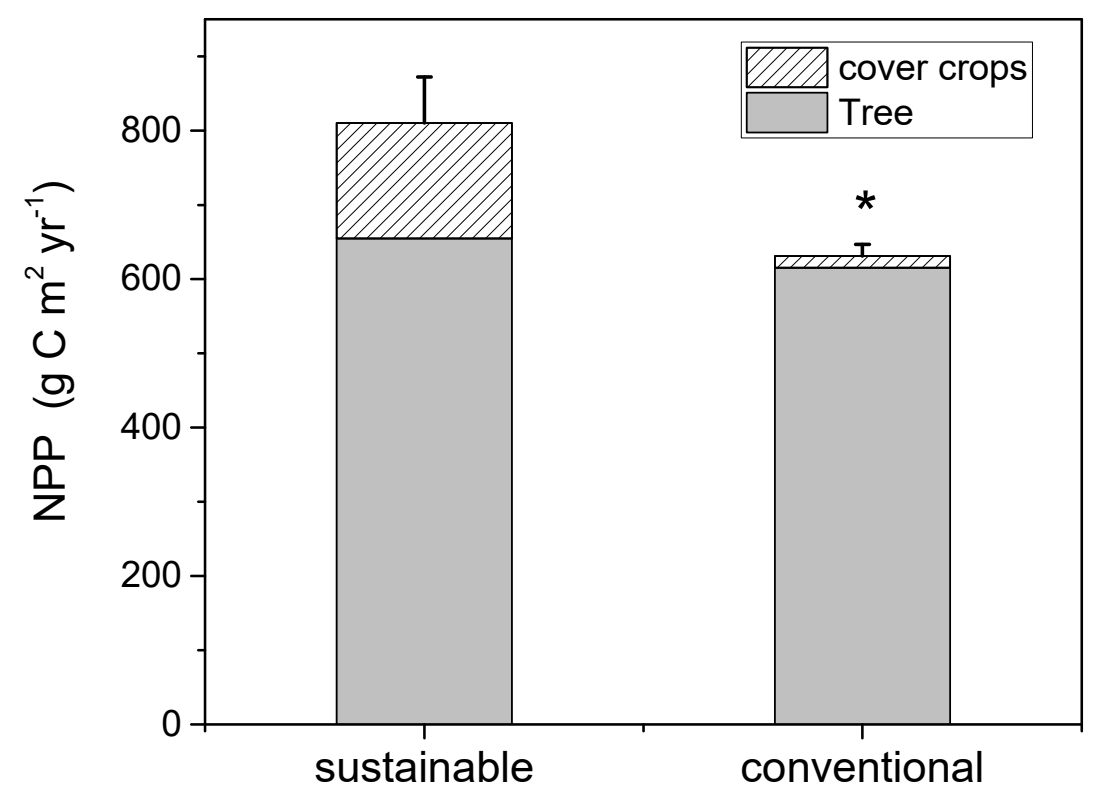

Figure 2. Values of annual trees and cover crop net primary productivity (NPP) measured at a Mediterranean peach orchard under different management options. Bars are SE and refers to the sum of tree and cover crop NPP; comparing the total NPP values for sustainable and conventional plot. ${ }^{*}$ indicates significant differences (Student's $t$-test, $\alpha=0.05$ ). Redrawn from [39].

Soil respiration $\left(R_{\mathrm{S}}\right)$ is a significant $\mathrm{C}$ flux from cropping system to the atmosphere ranging from $\sim 0.2$ to $\sim 1.6 \mathrm{~kg} \mathrm{C} \mathrm{m}^{-2} \mathrm{yr}^{-1}$ depending of various soil and environmental conditions [40]. Hence, efforts to minimize $R_{\mathrm{s}}$ would contribute to reduce the impact of agriculture on atmospheric $\mathrm{CO}_{2}$ and to maintain the soil $\mathrm{C}$ stock. Avoidance (or reduction) of soil disturbance through zero (or minimum) tillage is an essential management option to reduce soil $\mathrm{CO}_{2}$ emissions [41]. The $\mathrm{CO}_{2}$ emission might flush for approx. 2-25 days after soil disturbance depending mainly on the deep of tillage. Afterwards, emissions reach a base level similar to that of no tilled soil [18,41]. A meta-analysis covering different soil, climate types and time-scale (season, years) concluded that tillage on average increases $\mathrm{CO}_{2}$ emissions by approx. $20 \%$ compared to no-tillage [42].

The main effect of soil disturbance on $\mathrm{CO}_{2}$ emissions is the disruption of soil aggregates and in turn the exposure of SOC to microbial decomposition [18] highlighting that the $R_{\mathrm{h}}$ component is the most relevant one. Hence, it is not surprising that soil respiration might be up to $20 \%$ higher in a sustainable peach orchard (no tillage, cover crops, compost application and mulching of crop residues) compared to that of the paired tilled field because of the higher $\mathrm{C}$ inputs and SOC [43]. Increased $R_{\mathrm{S}}$ due to increasing organic matter decomposition is fueling the debate on the sustainability of organic inputs [44]. Further management efforts (e.g., disposal of $\mathrm{C}$ inputs in deep soil layer, use of in situ catalyzed oxidative polymerization) $[45,46]$ might be of assistance to reduce $\mathrm{CO}_{2}$ emissions due to high C content. However, $R_{\mathrm{S}}$ (and specifically the $R_{\mathrm{h}}$ component) needs to be considered within the whole ecosystem dimension (i.e., in combination with NPP as per Equation (1)) if its agroecology significance is to be defined.

Farmer's fields conform to an ecosystem where pools of material and energy are supplied not only by the biosphere and atmosphere but also by the anthroposphere to the extent that the ecosystem approach applies to it [47]. An ecosystem approach linking biotic, physics and anthropogenic $\mathrm{C}$ imports/exports is essential for sustainable management of 
cropland [47] and it has been conceptualized through the Net Ecosystem Carbon Balance (NECB) framework [48]. The NECB might be schematized as follow:

$$
\mathrm{NECB}=\mathrm{NEP}-\mathrm{LTC}
$$

where the LTC represents the lateral transport of carbon related to anthropogenic imports/exports such as fruit harvest, removing of pruning residuals and import of organic fertilizers. A schematic of the NECB is proposed in Figure 3.

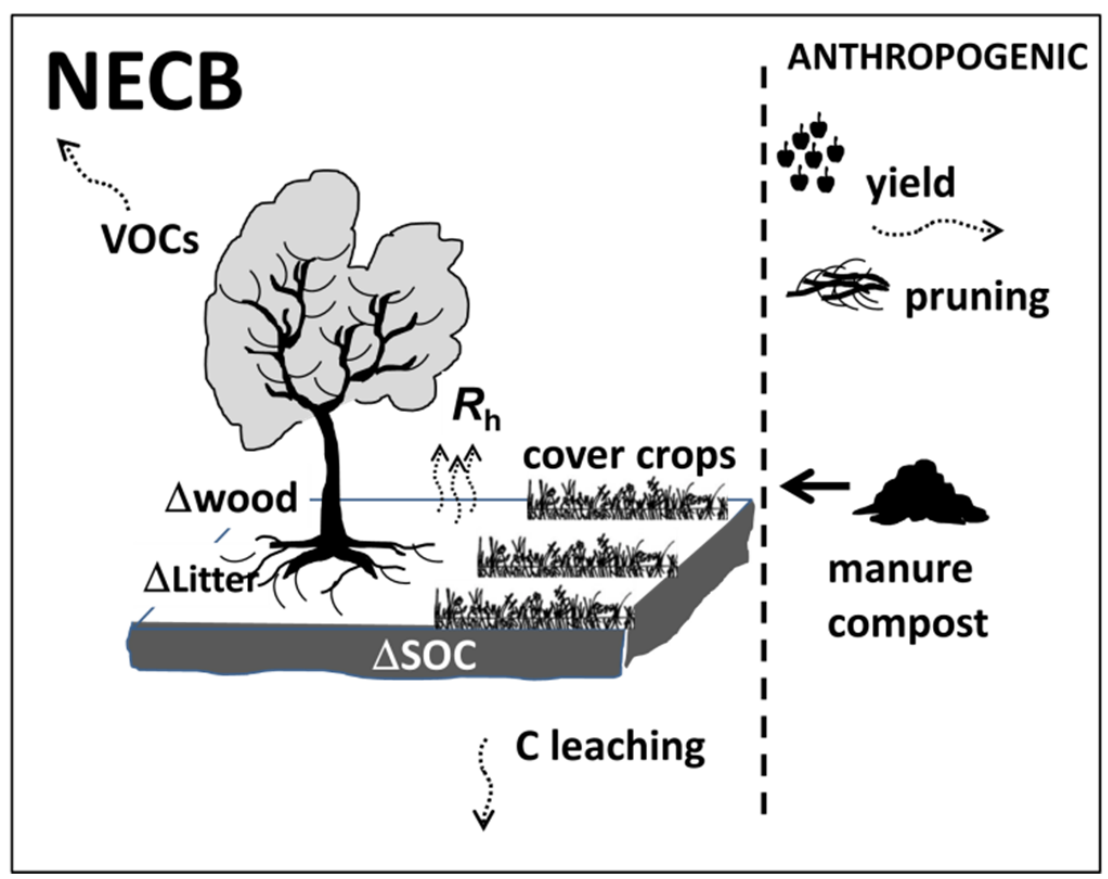

Figure 3. Schematic of the main $C$ fluxes accounted within the Net Ecosystem Carbon Balance (NECB) framework highlighting the lateral transport associated to the anthropogenic activities. $R_{\mathrm{h}}=$ heterotrophic respiration; $\mathrm{VOC}=$ volatile organic compound; $\mathrm{SOC}=$ soil organic carbon; wood $=$ structural above and belowground wood.

The NECB framework has been implemented in various tree crops resulting in net sink $(\mathrm{NECB}>0$ ) (Figure 4$)$. Values of NECB within tree crops are greatly variable and, in some cases, it could be vulnerable and easily fall in the negative territory, becoming a source (see peach_2 and apple_2 in Figure 4) just in case of increased C export due, for example, to an increased yield [49]. Upon the application of a set of sustainable practices (compost supply, recycling of pruning residuals, cover crops), $\mathrm{C}$ budget values might increase up to approx. $750 \mathrm{~g} \mathrm{C} \mathrm{m}^{-2} \mathrm{yr}^{-1}$ and be in the magnitude of that reported for a forestry species under woody ash and nitrogen application (see peah_1 and poplar in Figure 4). The NECB framework simultaneously captures $C$ fluxes related to human activity and to the biome photosynthesis (NPP) and soil respiration $\left(R_{\mathrm{h}}\right)$. However additional C fluxes (e.g., leaching, volatile organic compounds, $\mathrm{CH}_{4}, \mathrm{CO}, \mathrm{CO}_{2}$ emissions from fire) might be accounted within the NECB framework [48]. 


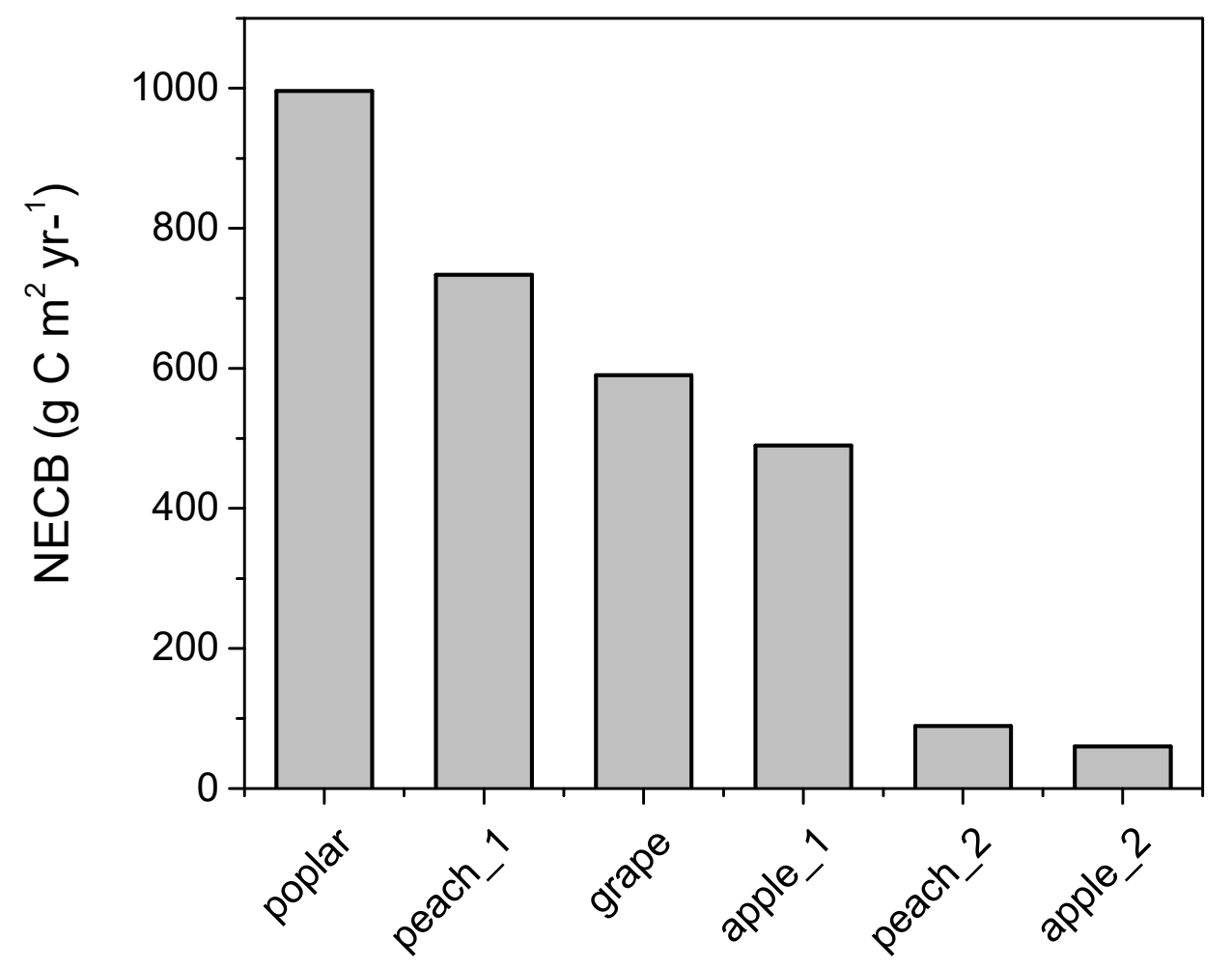

Figure 4. Values of annual Net Ecosystem Carbon Balance (NECB) in various tree species. Peach data are redrawn from [39]; apple and grape from [50,51].

\section{Global Dimension}

The global warming potential (GWP) has been introduced, as an environmental impact category, to normalize the contribution of a GHG to the radiative forcing of atmosphere relative to that of $\mathrm{CO}_{2}$ which is by definition equal to 1 . For example, at a 20-year time horizon the GWP related to the emission of one molecule of $\mathrm{CH}_{4}$ and $\mathrm{N}_{2} \mathrm{O}$ is equivalent to 84 and 264 molecules of $\mathrm{CO}_{2}$, respectively [4]. Agriculture might affect several impact categories (e.g., acidification, eutrophication, toxicity, ozone depletion) including GWP whose indicator is the emitted amount of $\mathrm{CO}_{2}$ or $\mathrm{CO}_{2}$-eq when non- $\mathrm{CO}_{2} \mathrm{GHG}$ gases are considered [52]. Application of sustainable practices benefits the overall atmospheric $\mathrm{CO}_{2}$ removal capacity of orchards contributing to the ecosystem resilience. However, some components (e.g., leaf, twigs, weed, most of annual root) of the annually produced ecosystem biomass have a relatively fast turnover (6-12 months) and therefore they have no net positive impact on the GWP. By contrast, according to IPCC agricultural carbon pools belonging SOC, the dead organic matter (litter and dead wood) and crop above and belowground coarse biomass has a long turnover and therefore is considered as $\mathrm{CO}_{2}$ sequestration rather than removal (Figure 5) [33]. Based on the durable feature of $C$ stored in these pools (soil, coarse biomass, litter) they can be monitored for GHGs national accounting purposes by Kyoto Protocol signatory countries [33] clearly underlying a global dimension of the sustainable practices adopted. The stock variation of these $\mathrm{C}$ pools is also tracked by the NECB framework, hence the ecosystem and global dimension (sensu IPCC) share some common features (Figures 3 and 5) that are to be considered to avoid any double accounting. 


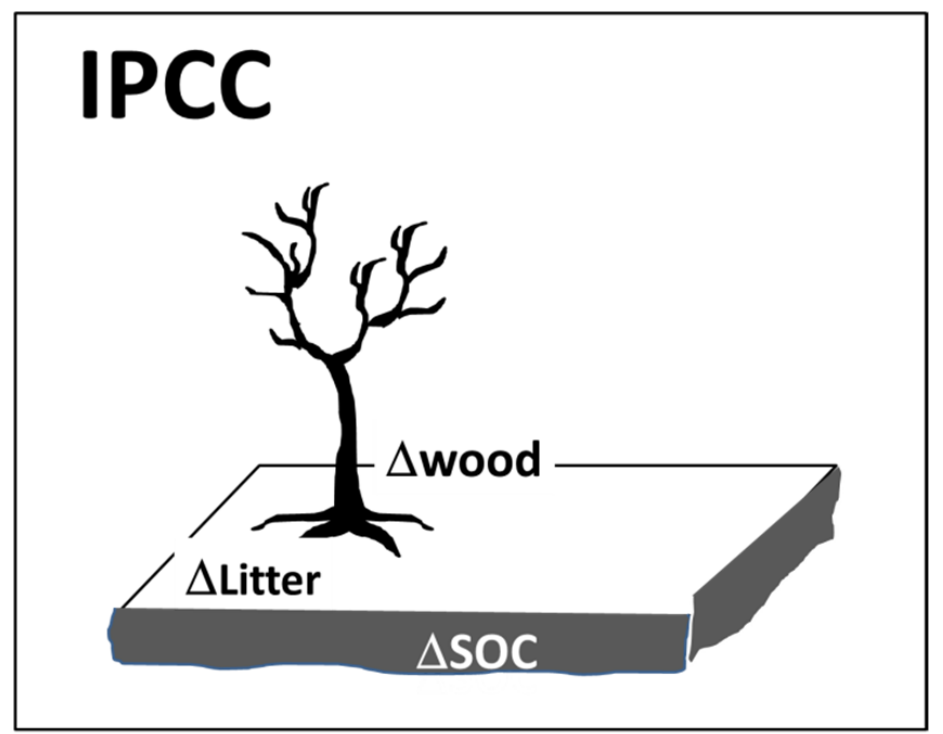

Figure 5. Illustration of the three pools at cultivated field whose $\mathrm{C}$ stock variations are accounted within the IPCC procedures [31]. SOC = soil organic carbon, wood = coarse above- and belowground wood. Note that these three pools are also included in the NECB framework (see Figure 3).

As an orchard is a managed ecosystem, the production cycle requires external inputs that imply GHGs emissions to be accounted if the assessment of orchard impact on GWP at a global dimension is to be determined. The use of machinery, pesticides, fertilizers, plastic trays for harvest, iron wire and plastic pipes for irrigation system, water pumping energy, etc. are roughly common on-site inputs supplied by the technosphere. In addition, there are often other off-site inputs (e.g., transportation, packhouse processing) essential for the whole agrifood production chain (Figure 6). The use of external inputs supplied by the technosphere implies direct or indirect GHGs emissions [12] which are not related to the biological ability of a crop system to sequester/release $C$ and therefore not tracked by the NECB framework.

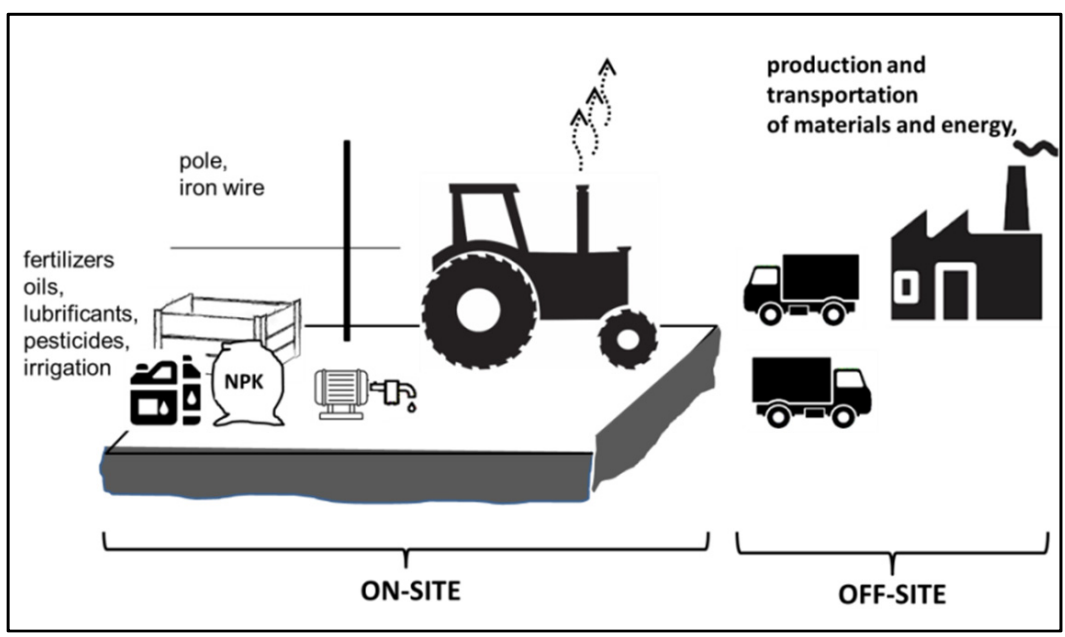

Figure 6. Schematic representation of typical inputs provided by the technosphere to the agrifood production used at field (on-site) or off-site. Note that the GHGs associated to these inputs are accounted within the life cycle assessment (LCA) framework.

Accounting for these direct and indirect GHGs emissions is mainly achieved through product-based life-cycle assessment (LCA) whose standards have been developed by ISO 14067 [21], contributing to a "global" assessment of sustainability. Recently, increasing 
demand for sustainable food and goods by consumers have further stimulated the need to quantify their environmental impact, which is increasingly communicated by suppliers through LCA-based labels $[53,54]$.

LCA methodology is often applied to the agrifood sector [55] but it brings uncertainties due to the interacting ecological and anthropogenic activities. The accuracy of LCA methodology in providing the environmental performance of a crop system is debated because of its limitations in accounting for ecosystem-based GHGs flux closely linked to management practices (e.g., soil quality, soil $\mathrm{C}$ sequestration and $\mathrm{N}$ emissions) [55]. Comparing the various frameworks for accounting $\mathrm{C}$ fluxes at similar orchard production contexts (Figure 7), it emerges that the LCA approach is tracking only the "bad" face (i.e., emissions) of agricultural practices in terms of GWP impact. In addition, comparing sustainable and conventional orchards biomass might not be greatly influenced by the management technique while soil and litter $C$ sequestration might significantly differ (see IPCC columns in Figure 7).

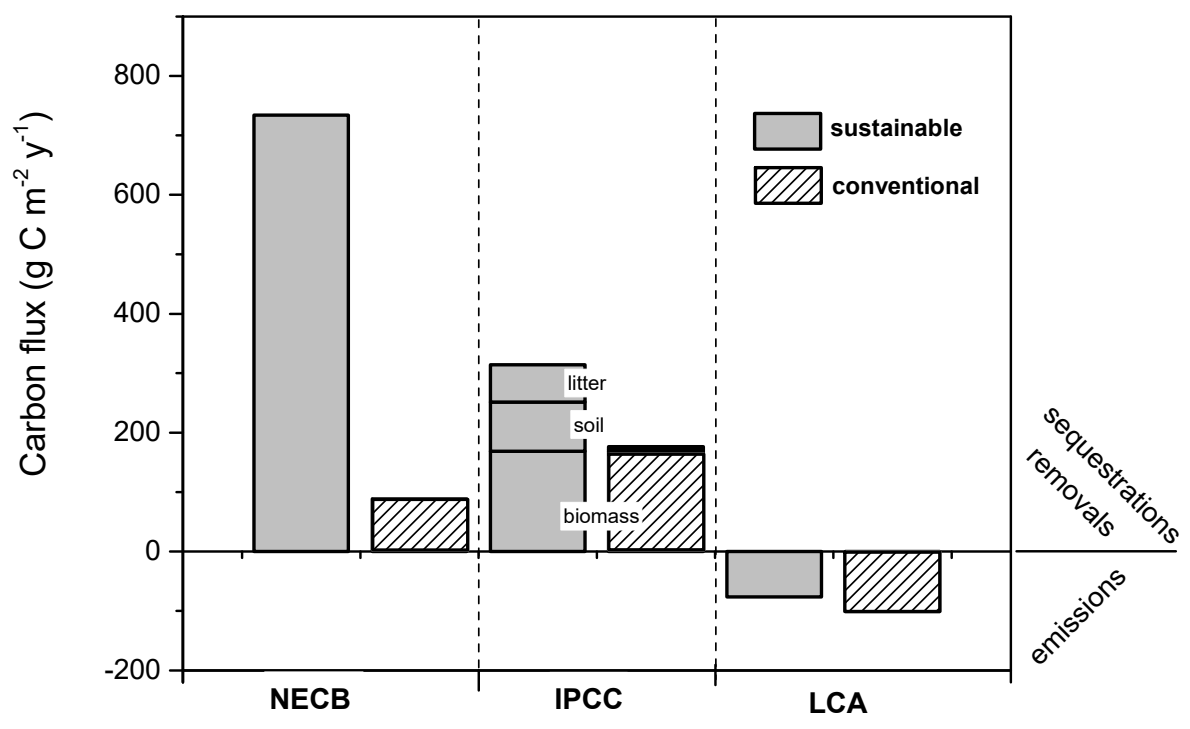

Figure 7. Mean annual carbon net removals and sequestrations (positive values) and emissions (negative values) determined at sustainable and conventional Mediterranean peach orchards by means of Net Ecosystem Carbon Balance (NECB), IPCC and Life Cycle Assessment (LCA) operational frameworks. Data are reworked from [39] (NECB, IPCC) and [12] (LCA). Note that LCA carbon data were from $\mathrm{CO}_{2}$ equivalent conversion.

Information on the (positive) impact of agricultural process at ecosystem dimension might favor a wider perception of the GWP mitigation of agriculture. Comparison of LCA based assessment of GWP impact of orchards under different managements is difficult because of variability in parameters such as the functional unit (e.g., land surface unit, fresh yield unit, bottled product, single tray), or the system boundaries (e.g., from extraction of raw materials constitutive of all productive tools and inputs to farm gate, or to supply chain hub or to consumer table) or time boundaries (e.g., from cradle to grave). For example, the impact of olive oil production might differ in relation to the boundary of the system defined (compare [55,56]).

Despite this, LCA is a powerful methodology to identify specific process/material to be improved/replaced to benefit the environmental impact [12], and it should be integrated with data relying on the ecosystem dimension of agriculture [27,57-59]. This would help to get a more powerful assessment of sustainable agriculture. However, ecosystem parameters potentially related to LCA have a higher site-to-site variability, hampering its use, barring the development of a regionalized LCA offering region-specific inventories and characterization factors [54]. It emerges that the current assessment of sustainability in 
cropping systems might be implemented at field, ecosystem and global dimensions using various $\mathrm{CO}_{2}$ accounting frameworks which partly share common components (Figure 8).

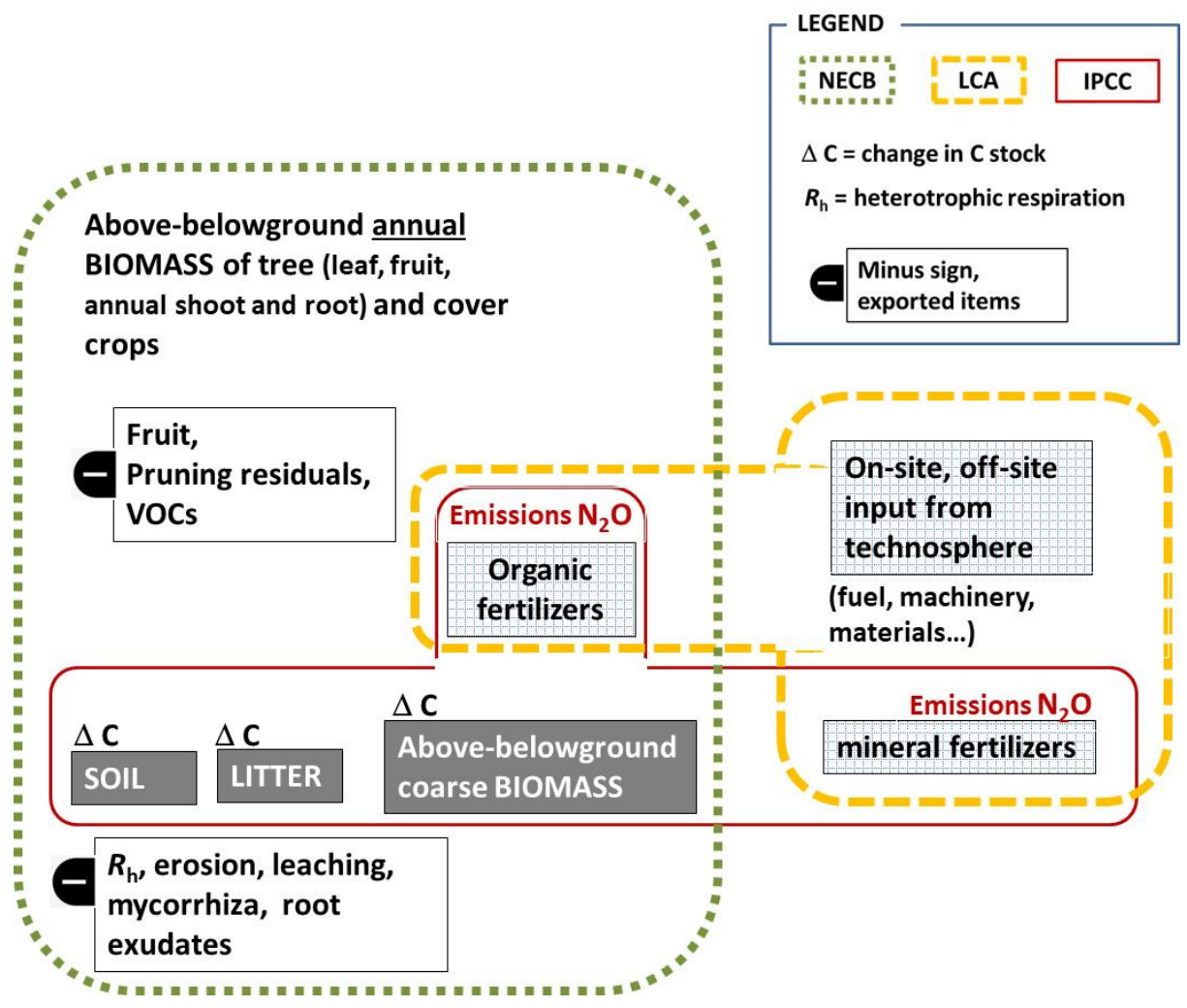

Figure 8. Schematic frameworks accounting for $\mathrm{CO}_{2}$ (e non- $\left.\mathrm{CO}_{2}\right)$ GHGs fluxes at ecosystem (NECB) and global (LCA, IPCC) dimensions. Note that organic and mineral fertilizers are on-site input from the technosphere.

\section{Product Environmental Footprint: The Uniqueness of the Olive Sector}

With the aim to harmonize the LCA-based methodology carried out for communicating the environmental performance of European agrifood products, the European Commission proposed a multi-criteria measure of the environmental performance of goods and services named Product Environmental Footprint [60]. The PEF was also intended to avoid confusion for consumers. Within agricultural systems, all tree crops (durably) sequester $C$ into above- and belowground coarse biomass to the extent that biomass represents an accountable pool for climate change mitigation purposes according to IPCC [33]. For the purposes of PEF, the general timeframe of 100 years is considered for the GWP calculation, hence the mean lifespan of tree crops (15-40 years) limits the inclusion of tree biomass to gain $\mathrm{C}$ credits in case of $\mathrm{GWP}_{100}$ calculation. However, among tree crops olive trees might stand for $>100$ years, deserving attention within product (e.g., olive oil) environmental footprint procedures.

Olive is among the most cultivated tree crop in Mediterranean countries which nowadays suffers land abandonment because of environmental and socio-economic constraints [61]. Olive crops might capture $\mathrm{CO}_{2}$ at a NEP rate as high as approx. $45 \mathrm{tCO}_{2}$ $\mathrm{ha}^{-1} \mathrm{yr}^{-1}$ (227 tree ha ${ }^{-1}$ ) representing a key valuable crop for climate change mitigation purpose [61]. The synergy between environmental and economic sustainability of olive groves has been the subject of recent researches depicting limitations and potentiality of the main existing LCA-based environmental certification processes of olive oil (for review [62]). Olive trees have some specific features which might help to introduce a novel integration among various environmental impact assessment frameworks, including the accounting of the biological capability of trees to sequester $\mathrm{CO}_{2}$. 
The PEF initiative included Product Environmental Footprint Category Rules (PEFCR) projects, launched by the European Commission in 2014 and now available in its last version [63]. The projects covered various animal and plant-based products, including olive oil within a context of "cradle to grave" assessments of final products footprint with a lifetime beyond 100 years.

In principle the PEFCR project was intended to account for emissions/removals occurring also at the field stage of each product considered. However, the biological function of plants to absorb atmospheric $\mathrm{CO}_{2}$ during the field stage was allowed only for the olive oil (and cork) product category, accounting for the olive tree biomass carbon sequestration occurred during the olive production. Explanation for that uniqueness was grounded on the evidence that an olive grove lifespan is greater than 100 years, justifying carbon credits for olive oil.

To test the process for developing product- and sector-specific PEFCR, a series of pilots (https:/ / ec.europa.eu/environment/eussd/smgp/PEFCR_OEFSR_en.htm, accessed on 15 May 2021) study were implemented for various products including olive oil, producing a screening report (PEFCR-OO) [64]). However, some issues still limit a systematic inclusion of biogenic carbon of olive tree biomass in LCA-based procedures due to some differences in olive grove cultivation systems among the main producing countries (i.e., Spain, Italy, Greece) $[65,66]$ and due to issue(s) not covered by the PEFCR-OO. For example, olive cropping systems might vary according to the plantation density and in turn differ in terms of carbon sequestration capability and lifespan duration. This in turn would impact the environmental footprint but, as for Spain, the high- or super high-density systems (> 1500 trees $\mathrm{ha}^{-1}$ ) were not considered within the PEFCR-OO pilots.

Despite the fact that annual carbon uptake by the tree biomass (e.g., leaves, pruning residues, fruits) in super high-density systems is greater than that of low and medium density groves [67], the potential C credits generated by the long-period biomass carbon storage (i.e., sequestration) could not be considered due to their lifespan generally assumed to be $<100$ years (i.e., 20 years) [68]. However, the last (v.6.3) version of PEFCR (par. 7.10.2) [63] recommended to adopt crop-type and country-region or climate specific data for all inputs referred to the crop management and yield. Hence, input data (e.g., pesticides, fertilizers, soil management, biomass) should be also tailored to specific cropping systems as defined by plantation density.

The PEFCR-OO project also considered the Italian and Greek olive cropping systems which similarly presents a higher degree of complexity due to the coexistence of various cultivation systems. Principally, approx. $60 \%$ of the total olive cropped area is covered by traditional (centuries-old) system (80-100 trees ha ${ }^{-1}$ ) and intensive (200-500 trees ha ${ }^{-1}$ ), while $40 \%$ is covered by a high-density system with a plantation density ranging from approx. 400 to 1500 trees ha ${ }^{-1}$. In these countries, super high-density plantations (>1500 tree ha ${ }^{-1}$ ) share a minimal percentage $(\sim 1 \%)$. For centuries-old tree plantations the long-period carbon sequestration has been allowed within the field stage, even though a specific calculation methodology remains to be fully developed. According to the PEFCR, in all these different olive cropping systems as for other tree crop species, the modelled long-term soil carbon storage (e.g., through RothC) might be accounted for carbon credits [12,69]. Again, considering the variability of soil properties (e.g., texture, clay content, moisture), environmental conditions (e.g., precipitation, temperature) and management practices (e.g., conventional tillage, cover crops) which collectively impact soil carbon turnover, the application of such a modelling procedure would be site-specific, limiting its generalization.

\section{Conclusions}

Agricultural crops are perceived as a large contributor to climate change but they also have relevant mitigation potential due to the storage of $C$ in the three pools belonging to cropping systems (soil, above and belowground biomass, litter). This study examined the carbon fluxes related to orchard production systems, considering the farm, ecosystem and global dimension. The main outcomes show that carbon fluxes in and out of the field might 
be defined and referred to at various dimensions through $\mathrm{CO}_{2}$ accounting frameworks (e.g., NECB, LCA, IPCC) which partly share common components and therefore might be used to scale sustainability across these dimensions. LCA-based procedures for communication of the environmental impact of an agrifood product reports only the GHG emissions associated to the use of technosphere inputs while the $\mathrm{CO}_{2}$ removals due to the biome remain hidden. Therefore, the influence of cropland activity on GWP impact category as measured through $\mathrm{CO}_{2}$ (or $\mathrm{CO}_{2}$-eq) emissions might be assessed considering not only emissions but also $\mathrm{CO}_{2}$ removals/sequestrations contributing to define sustainability of cropping systems at a global scale. In conclusion, the harmonization of various frameworks is desirable along with the integration of others ecosystem services components for a more comprehensive and detailed mapping of sustainability in agriculture.

Author Contributions: Conceptualization, G.M. All authors wrote the paper. All authors have read and agreed to the published version of the manuscript.

Funding: This research was funded by the 2014-2020 Rural Development Programme of Basilicata Region (Misura 16.1, GO INNO_OLIVO\&OLIO, CUP C31B18000590002 and IN.VINI.VERITAS, CUP G64D20000000006).

Institutional Review Board Statement: Not applicable.

Informed Consent Statement: Not applicable.

Data Availability Statement: Page: 12 Data will be available upon request.

Conflicts of Interest: The authors declare no conflict of interest.

\section{References}

1. United Nations. Sustainable development goals. In Arab Development Outlook; United Nations: New York, NY, USA, 2016; Annex I; p. 155.

2. Pacini, G.C.; Groot, J.C.J. Sustainability of agricultural management options under a systems perspective. In Encyclopedia of Sustainable Technologies, 1st ed.; Abraham, M., Ed.; Elsevier: Amsterdam, The Netherlands, 2017; pp. 191-200.

3. Robertson, G.P. Greenhouse gases in intensive agriculture: Contributions of individual gases to the radiative forcing of the atmosphere. Science 2000, 289, 1922-1925. [CrossRef] [PubMed]

4. Pulselli, F.M.; Marchi, M. Global warming potential and the net carbon balance. Ref. Modul. Earth Syst. Environ. Sci. 2015. [CrossRef]

5. Binswanger, H. Agricultural mechanization. World Bank Res. Obs. 1986, 1, 27-56. [CrossRef]

6. Aguilera, E.; Vila-Traver, J.; Deemer, B.R.; Infante-Amate, J.; Guzmán, G.I.; González de Molina, M. Methane emissions from artificial waterbodies dominate the carbon footprint of irrigation: A study of transitions in the food-energy-water-climate nexus (Spain, 1900-2014). Environ. Sci. Technol. 2019, 53, 5091-5101. [CrossRef] [PubMed]

7. Villarino, S.H.; Studdert, G.A.; Laterra, P. How does soil organic carbon mediate trade-offs between ecosystem services and agricultural production? Ecol. Indic. 2019, 103, 280-288. [CrossRef]

8. Montanaro, G.; Xiloyannis, C.; Nuzzo, V.; Dichio, B. Orchard management, soil organic carbon and ecosystem services in Mediterranean fruit tree crops. Sci. Hortic. 2017, 217, 92-101. [CrossRef]

9. Mosier, A.; Schimel, D.; Valentine, D.; Bronson, K.; Parton, W. Methane and nitrous oxide fluxes in native, fertilized and cultivated grasslands. Nature 1991, 350, 330-332. [CrossRef]

10. Maris, S.C.; Teira-Esmatges, M.R.; Arbonés, A.; Rufat, J. Effect of irrigation, nitrogen application, and a nitrification inhibitor on nitrous oxide, carbon dioxide and methane emissions from an olive (Olea europaea L.) orchard. Sci. Total Environ. 2015, 538, 966-978. [CrossRef] [PubMed]

11. Smith, P.; Martino, D.; Cai, Z.; Gwary, D.; Janzen, H.; Kumar, P.; McCarl, B.; Ogle, S.; O'Mara, F.; Rice, C.; et al. Greenhouse gas mitigation in agriculture. Philos. Trans. R. Soc. Lond. B Biol. Sci. 2008, 363, 789-813. [CrossRef]

12. Fiore, A.; Lardo, E.; Montanaro, G.; Laterza, D.; Loiudice, C.; Berloco, T.; Dichio, B.; Xiloyannis, C. Mitigation of global warming impact of fresh fruit production through climate smart management. J. Clean. Prod. 2018, 172, 3634-3643. [CrossRef]

13. Lal, R. Beyond COP21: Potential and challenges of the 4 per Thousand initiative. J. Soil Water Conserv. 2016, 71, 20-25. [CrossRef]

14. Aguilera, E.; Lassaletta, L.; Gattinger, A.; Gimeno, G.S. Managing soil carbon for climate change mitigation and adaptation in Mediterranean cropping systems: A meta-analysis. Agric. Ecosyst. Environ. 2013, 168, 25-36. [CrossRef]

15. IPCC. Climate Change and Land: An IPCC Special Report on Climate Change, Desertification, Land Degradation, Sustainable Land Management, Food Security, and Greenhouse Gas Fluxes in Terrestrial Ecosystems; Shukla, P.R., Skea, J., Calvo Buendia, E., Masson-Delmotte, V., Pörtner, H.-O., Roberts, D.C., Zhai, P., Slade, R., Connors, S., van Diemen, R., et al., Eds.; IPCC: Geneva, Switzerland, 2019. 
16. Chen, J.; Gong, Y.; Wang, S.; Guan, B.; Balkovic, J.; Kraxner, F. To burn or retain crop residues on croplands? An integrated analysis of crop residue management in China. Sci. Total Environ. 2019, 662, 141-150. [CrossRef]

17. Lal, R. Soil health and carbon management. Food Energy Secur. 2016, 5, 212-222. [CrossRef]

18. La Scala, N.; Marques, J.; Pereira, G.T.; Cora, J.E. Short-term temporal changes in the spatial variability model of $\mathrm{CO}_{2}$ emissions from a Brazilian bare soil. Soil Biol. Biochem. 2000, 32, 1459-1462. [CrossRef]

19. Aschemann-Witzel, J.; Gantriis, R.F.; Fraga, P.; Perez-Cueto, F.J. Plant-based food and protein trend from a business perspective: Markets, consumers, and the challenges and opportunities in the future. Crit. Rev. Food Sci. Nutr. 2020, 1-10. [CrossRef] [PubMed]

20. Pampuro, N.; Caffaro, F.; Cavallo, E. Farmers' attitudes toward on-farm adoption of soil organic matter in piedmont region, Italy. Agriculture 2020, 10, 14. [CrossRef]

21. International Standard Organization. Greenhouse Gases_Carbon Footprint of Products—Requirements and Guidelines for Quantification; ISO: Geneva, Switzerland, 2018.

22. Cordes, H.; Iriarte, A.; Villalobos, P. Evaluating the carbon footprint of Chilean organic blueberry production. Int. J. Life Cycle Assess. 2016, 21, 281-292. [CrossRef]

23. Gadema, Z.; Oglethorpe, D. The use and usefulness of carbon labelling food: A policy perspective from a survey of UK supermarket shoppers. Food Policy 2011, 36, 815-822. [CrossRef]

24. Feller, C.; Blanchart, E.; Bernoux, M.; Lal, R.; Manlay, R. Soil fertility concepts over the past two centuries: The importance attributed to soil organic matter in developed and developing countries. Arch. Agron. Soil Sci. 2012, 58, S3-S21. [CrossRef]

25. Manlay, R.J.; Feller, C.; Swift, M.J. Historical evolution of soil organic matter concepts and their relationships with the fertility and sustainability of cropping systems. Agric. Ecosyst. Environ. 2007, 119, 217-233. [CrossRef]

26. Fageria, N.K. Soil fertility and plant nutrition research under field conditions: Basic principles and methodology. J. Plant Nutr. 2007, 30, 203-223. [CrossRef]

27. Petersen, E.H.; Hoyle, F.C. Estimating the economic value of soil organic carbon for grains cropping systems in Western Australia. Soil Res. 2016, 54, 383. [CrossRef]

28. Didion, M.; Blujdea, V.; Grassi, G.; Hernández, L.; Jandl, R.; Kriiska, K.; Lehtonen, A.; Saint-André, L. Models for reporting forest litter and soil $\mathrm{C}$ pools in national greenhouse gas inventories: Methodological considerations and requirements. Carbon Manag. 2016, 7, 79-92. [CrossRef]

29. Agumas, B.; Blagodatsky, S.; Balume, I.; Musyoki, M.K.; Marhan, S.; Rasche, F. Microbial carbon use efficiency during plant residue decomposition: Integrating multi-enzyme stoichiometry and C balance approach. Appl. Soil Ecol. 2021, 159, 103820. [CrossRef]

30. Kallenbach, C.M.; Wallenstein, M.D.; Schipanksi, M.E.; Grandy, A.S. Managing Agroecosystems for Soil Microbial Carbon Use Efficiency: Ecological Unknowns, Potential Outcomes, and a Path Forward. Front. Microbiol. 2019, 10, 1146. [CrossRef]

31. Xu, J.; Han, H.; Ning, T.; Li, Z.; Lal, R. Long-term effects of tillage and straw management on soil organic carbon, crop yield, and yield stability in a wheat-maize system. Field Crops Res. 2019, 233, 33-40. [CrossRef]

32. Hijbeek, R.; van Ittersum, M.K.; Berge, H.F.M.; Gort, G.; Spiegel, H.; Whitmore, A.P. Do organic inputs matter-A meta-analysis of additional yield effects for arable crops in Europe. Plant Soil 2016, 411, 293-303. [CrossRef]

33. Eggleston, H.S.; Buendia, L.; Miwa, K.; Ngara, T.; Tanabe, K. IPCC Guidelines for National Greenhouse Gas Inventories; ICCP: Ridderkerk, The Netherlands, 2006.

34. European Council. Decision No. 529/2013/EU of the European Parliament and of the Council on accounting rules on greenhouse gas emissions and removals resulting from activities relating to land use, land-use change and forestry and on information concerning actions relating to those activities. Off. J. Eur. Union 2013, L165, 80-97.

35. Guenet, B.; Gabrielle, B.; Chenu, C.; Arrouays, D.; Balesdent, J.; Bernoux, M.; Bruni, E.; Caliman, J.P.; Cardinael, R.; Chen, S.; et al. Can $\mathrm{N}_{2} \mathrm{O}$ emissions offset the benefits from soil organic carbon storage? Glob. Chang. Biol. 2020, 27, 237-256. [CrossRef]

36. Chamizo, S.; Serrano-Ortiz, P.; López-Ballesteros, A.; Sánchez-Cañete, E.P.; Vicente-Vicente, J.L.; Kowalski, A.S. Net ecosystem $\mathrm{CO}_{2}$ exchange in an irrigated olive orchard of SE Spain: Influence of weed cover. Agric. Ecosyst. Environ. 2017, 239, 51-64. [CrossRef]

37. McGourty, G.T.; Reganold, J.P. Managing vineyard soil organic matter with cover crops. In Proceedings of the Soil Environment and Vine Mineral Nutrition, San Diego, CA, USA, 29-30 June 2004; American Society for Enology and Viticulture: Davis, CA, USA, 2005; pp. 145-151.

38. Guzmán, G.; Cabezas, J.M.; Sánchez-Cuesta, R.; Lora, Á.; Bauer, T.; Strauss, P.; Winter, S.; Zaller, J.G.; Gómez, J.A. A field evaluation of the impact of temporary cover crops on soil properties and vegetation communities in southern Spain vineyards. Agric. Ecosyst. Environ. 2019, 272, 135-145. [CrossRef]

39. Montanaro, G.; Tuzio, A.C.; Xylogiannis, E.; Kolimenakis, A.; Dichio, B. Carbon budget in a Mediterranean peach orchard under different management practices. Agric. Ecosyst. Environ. 2017, 238, 104-113. [CrossRef]

40. Chen, S.; Zou, J.; Hu, Z.; Chen, H.; Lu, Y. Global annual soil respiration in relation to climate, soil properties and vegetation characteristics: Summary of available data. J. Agric. Meteorol. 2014, 198-199, 335-346. [CrossRef]

41. Reicosky, D.C. Tillage-induced $\mathrm{CO}_{2}$ emission from soil. Nutr. Cycl. Agroecosyst. 1997, 49, 273-285. [CrossRef]

42. Abdalla, K.; Chivenge, P.; Ciais, P.; Chaplot, V. No-tillage lessens soil CO2 emissions the most under arid and sandy soil conditions: Results from a meta-analysis. Biogeosciences 2016, 13, 3619-3633. [CrossRef] 
43. Montanaro, G.; Dichio, B.; Briccoli Bati, C.; Xiloyannis, C. Soil management affects carbon dynamics and yield in a Mediterranean peach orchard. Agric. Ecosyst. Environ. 2012, 161, 46-54. [CrossRef]

44. Navarro-Pedreño, J.; Almendro-Candel, M.B.; Zorpas, A.A. The Increase of soil organic matter reduces global warming, myth or reality? Science 2021, 3, 18. [CrossRef]

45. Nuzzo, A.; Spaccini, R.; Cozzolino, V.; Moschetti, G.; Piccolo, A. In situ polymerization of soil organic matter by oxidative biomimetic catalysis. Chem. Biol. Technol. Agric. 2017, 4, 12. [CrossRef]

46. Ray, R.L.; Griffin, R.W.; Fares, A.; Elhassan, A.; Awal, R.; Woldesenbet, S.; Risch, E. Soil $\mathrm{CO}_{2}$ emission in response to organic amendments, temperature, and rainfall. Sci. Rep. 2020, 10, 5849. [CrossRef] [PubMed]

47. Chapin, F.S., III; Matson, P.A.; Vitousek, P.M. Managing and sustaining ecosystems. In Principles of Terrestrial Ecosystem Ecology; Springer: New York, NY, USA, 2011; pp. 423-447.

48. Chapin, F.S., III; Woodwell, G.M.; Randerson, J.T.; Rastetter, E.B.; Lovett, G.M.; Baldocchi, D.D.; Clark, D.A.; Harmon, M.E.; Schimel, D.S.; Valentini, R.; et al. Reconciling carbon-cycle concepts, terminology, and methods. Ecosystems 2006, 9, 1041-1050. [CrossRef]

49. Zanotelli, D.; Montagnani, L.; Manca, G.; Scandellari, F.; Tagliavini, M. Net ecosystem carbon balance of an apple orchard. Eur. J. Agron. 2015, 63, 97-104. [CrossRef]

50. Scandellari, F.; Caruso, G.; Liguori, G.; Meggio, F.; Palese, A.M.; Zanotelli, D.; Celano, G.; Gucci, R.; Inglese, P.; Pitacco, A.; et al. A survey of carbon sequestration potential of orchards and vineyards in Italy. Eur. J. Hortic. Sci. 2016, 81, 106-114. [CrossRef]

51. Ventura, M.; Panzacchi, P.; Muzzi, E.; Magnani, F.; Tonon, G. Carbon balance and soil carbon input in a poplar short rotation coppice plantation as affected by nitrogen and wood ash application. New For. 2019, 50, 969-990. [CrossRef]

52. Tsangas, M.; Gavriel, I.; Doula, M.; Xeni, F.; Zorpas, A.A. Life cycle analysis in the framework of agricultural strategic development planning in the balkan region. Sustainability 2020, 12, 1813. [CrossRef]

53. Cerutti, A.K.; Beccaro, G.L.; Bosco, S.; De Luca, A.I.; Falcone, G.; Fiore, A.; Iofrida, N.; Lo Giudice, A.; Strano, A. Life cycle assessment in the fruit sector. In Life Cycle Assessment in the Agri-Food Sector; Springer: New York City, NY, USA, 2015; pp. 333-388.

54. Pattara, C.; Russo, C.; Antrodicchia, V.; Cichelli, A. Carbon footprint as an instrument for enhancing food quality: Overview of the wine, olive oil and cereals sectors. J. Sci. Food Agric. 2016, 97, 396-410. [CrossRef] [PubMed]

55. Solinas, S.; Tiloca, M.T.; Deligios, P.A.; Cossu, M.; Ledda, L. Carbon footprints and social carbon cost assessments in a perennial energy crop system: A comparison of fertilizer management practices in a Mediterranean area. Agric. Syst. 2021, 186, 102989. [CrossRef]

56. Stillitano, T.; Falcone, G.; De Luca, A.I.; Piga, A.; Conte, P.; Strano, A.; Gulisano, G. A life cycle perspective to assess the environmental and economic impacts of innovative technologies in extra virgin olive oil extraction. Foods 2019, 8, 209. [CrossRef]

57. Proietti, S.; Sdringola, P.; Regni, L.; Evangelisti, N.; Brunori, A.; Ilarioni, L.; Nasini, L.; Proietti, P. Extra virgin olive oil as carbon negative product: Experimental analysis and validation of results. J. Clean. Prod. 2017, 166, 550-562. [CrossRef]

58. Goglio, P.; Smith, W.N.; Grant, B.B.; Desjardins, R.L.; McConkey, B.G.; Campbell, C.A.; Nemecek, T. Accounting for soil carbon changes in agricultural life cycle assessment (LCA): A review. J. Clean. Prod. 2015, 104, 23-39. [CrossRef]

59. Van der Werf, H.M.G.; Knudsen, M.T.; Cederberg, C. Towards better representation of organic agriculture in life cycle assessment. Nat. Sustain. 2020, 3, 419-425. [CrossRef]

60. European Commission. Commission Recommendation of 9 April 2013 on the Use of Common Methods to Measure and Communicate the Life Cycle Environmental Performance of Products and Organisations. Off. J. Eur. Union 2013, L124, 1-210.

61. Montanaro, G.; Nuzzo, V.; Xiloyannis, C.; Dichio, B. Climate change mitigation and adaptation in agriculture: The case of olive. J. Water Clim. Chang. 2018, 9, 633-642. [CrossRef]

62. Lombardo, L.; Farolfi, C.; Capri, E. Sustainability certification, a new path of value creation in the olive oil sector: The Italian case study. Foods 2021, 10, 501. [CrossRef] [PubMed]

63. European Commission. European Commission, PEFCR Guidance Document-Guidance for the Development of Product Environmental Footprint Category Rules (PEFCRs), Version 6.3. May 2018. Available online: https://ec.europa.eu/environment/ eussd/smgp/pdf/PEFCR_guidance_v6.3.pdf (accessed on 15 July 2020).

64. Technical Secretariat for Olive Oil. Product Environmental Footprint Category Rules for Olive Oil. Available online: https: / / ec.europa.eu/environment/eussd/smgp/pdf/pilots/draft_pefcr_olive_oil_pilot_for_3rd_consultation.pdf (accessed on 10 May 2021).

65. Russo, C.; Cappelletti, G.M.; Nicoletti, G.M.; di Noia, A.E.; Michalopoulos, G. Comparison of European Olive Production Systems. Sustainability 2016, 8, 825. [CrossRef]

66. Russo, C.; Tuomisto, H.L.; Michalopoulos, G.; Pattara, C.; Polo Palomino, J.A.; Cappelletti, G.M.; Nicoletti, G.M. Product environmental footprint in the olive oil sector: State of the art. Environ. Eng. Manag. J. 2016, 15, 2019-2027. [CrossRef]

67. Mairech, H.; López-Bernal, Á.; Moriondo, M.; Dibari, C.; Regni, L.; Proietti, P.; Villalobos, F.J.; Testi, L. Is new olive farming sustainable? A spatial comparison of productive and environmental performances between traditional and new olive orchards with the model OliveCan. Agric. Syst. 2020, 181, 102816. [CrossRef]

68. Egea, G.; Fernández, J.E.; Alcon, F. Financial assessment of adopting irrigation technology for plant-based regulated deficit irrigation scheduling in super high-density olive orchards. Agric. Water Manag. 2017, 187, 47-56. [CrossRef]

69. Nieto, O.M.; Castro, J.; Fernández, E.; Smith, P. Simulation of soil organic carbon stocks in a Mediterranean olive grove under different soil-management systems using the RothC model. Soil Use Manag. 2010, 26, 118-125. [CrossRef] 